\title{
The Missionary Press of Asia, 1550 - 1860
}

by Jobn A. Lent

Nearly any student of the history of printing in the West knows of the close links that were forged between Christianity and the early presses. They know that Gutenberg's first major work was a Bible and that the first publications that came off many presses in the Christianized West were religious books and tracts.

But what has remained relatively obscure is the impact of Christianity upon the establishment of the first presses in many non-Christian nations. Asia is an example. In country after country in Asia, Catholic and Protestant missionaries were responsible for setting up the first printing presses and/or publishing the first periodicals. Catholic missionaries were publishing in at least Macao, Japan, the Philippines and India in the sixteenth century. Protestant missionaries from the United States and Europe came along later and introduced the first presses and/or periodicals in at least Burma, Thailand, Malaya, Singapore, Indonesia and parts of China. The names of some of these missionaries, e.g., Robert Morrison, William Milne and Walter H. Medhurst, saturate the literature on early nineteenth century journalism in Asia.

In this article, an attempt will be made to document the existence of missionary presses in East and Southeast Asia (Japan, the Philippines, Indonesia, China, Hong Kong, Macao, Malaysia, Singapore, Burma and Thailand) ${ }^{1}$ and in South Asia (India and Ceylon).

\section{East and Southeast Asia}

Japan:

Among the first presses brought to Asia was that acquired by the Portuguese missionary, Diogo de Mesquita, S.J., while on a visit to Europe in 1586. De Mesquita housed his Japanese-language press in the Santiago Hospital in Nagasaki, where it functioned from 1586 until the missionary's death on November 4,1614 . The press was used primarily to publish ecclesiastical works, the first of which was Guia de Pecadores in the Japanese language. Within a week after de Mesquita's death, the missionaries were sent into exile to Macao and took their press with them.2.

Block printing, dating to at least 764 A.D., had dominated the scene in Japan until the last decade of the sixteenth century. Even before the arrival of the Jesuits, printing was considered the domain of religious authorities; all block printing, for example, was done by Buddhists working mainly in their temples on Buddhism books. One source ${ }^{3}$, claiming the period of movable type began in 1590 and had its supremacy only from $1600-1640$, reported that the printing technique was introduced almost simultaneously from two sources - Portugal and Korea. In 1592, Japan, looking for an overseas empire, unsuccesfully invaded Korea. One of the positive outcomes was that the soldiers returned with presses complete with types which were used to print a Chinese classic, Kobun Kókyó in 1593. The Japanese authorities enthusiastically supported printing

Dr. John A. Lent ist Professor für Kommunikation an der Temple University, Philadelphia. Er war "Fulbright Scholar" auf den Philippinen 1964-1965 und leitete das erste akademische Programm für Massenkommunikation in Malaysia, 1972-1974. 
from the Korean movable type presses, which were also used by private printers working in Buddhist temples under the sponsorhip of wealthy patrons, by temple personnel doing Buddhist texts and by commercial printers ${ }^{4}$.

Despite the great interest in movable type during the early seventeenth century, the technique nearly disappeared in Japan after 1650 when block printing was revived ${ }^{5}$.

Much later, when Japan accepted the idea of newspaper publishing in the $1860 \mathrm{~s}$, a Christian missionary was involved with one of the earliest newspapers. Bankoku Shimbun (Universal News), started in January 1867 as the third Japanese newspaper and the first by a foreigner, was the product of the Rev. Buchworth Baily, the English consular chaplain ${ }^{6}$. At that time, it was the practice to reproduce Chinese newspapers, translating into Japanese all news except that of Christianity which was banned by the Tokugawa authorities.

\section{Philippines:}

Another country of the region where the missionaries early introduced printing was the Philippines. The Dominicans, a Roman Catholic order, established the first press, which in 1593, published Doctrina Christiana. There is some belief that the Dominican press was brought from Goa or Japan where missionaries were already printing ${ }^{7}$. By 1606, Franciscans had started a press in Tayabas to print dictionaries and ecclesiastical works, and in 1611, the Augustinians brought their press from Japan ${ }^{8}$. They sold it to the Jesuits in 1622. Later, when the Jesuits were banned from the islands, their press was confiscated by the state and placed in the University of Santo Tomas (operated by the Dominicans), making it the owner of two presses.

By the beginning of the eighteenth century, according to Valenzuela, various missionary orders had been accomplishing their aims through the printed word: "From their presses were issued rare and much esteemed books - history, chronicles, decrees, grammar, verses, sermons, life of the saints, pastoral and scientific works, moral, dictionary, confessionary, guide to sinners, precepts, religious tenets." ${ }^{\prime 9}$ From 1593 to the nineteenth century, Valenzuela said 541 books had been published in the Philippines.

By February 1861, a religious newspaper, El Católico Filipino, was published, and in 1876, the first religious journal, Boletín Eclesiastico del Arzobispado de Manila. In both cases, these were late starting dates, as there were newspapers published in Manila since 1811. Valenzuela also comments on this point: "It seems paradoxical that there had been very few publications that were devoted to religion in the Philippines when the very purpose of Spain's colonization was principally to propagate her religion ... The religious orders were the ones who gave birth in the Philippines to the art of printing." 10

\section{Indonesia:}

As is the case with a few other countries, there is some conflict about the origins of the press in Indonesia. McMurtrie wrote that the consistory of the Dutch Reformed Church (Batavia) had printing equipment in 1624 but that it remained idle for lack of skilled printers $^{11}$. De Graaf disagreed slightly, saying there had been an unsuccessful attempt to establish a printing office in 1524 to publish legal regulations and to help 
the Dutch Reformed Church promote its beliefs ${ }^{12}$. About 75 years after the Supreme Government took the initiative in starting a printing house in 1667 , the first successful mission printing operation, Seminary Press, was set up ${ }^{13}$. Gustaaf Willem Baron van Imhoff, governor-general of Ceylon in 1736-38 and of Indonesia in $1743-50$, urged the Dutch authorities in 1741 to send printing equipment to Batavia and Ceylon to propagate Christianity. In 1742, he personally brought new equipment and personnel and the Seminary Press was created on May 28, 1743. A number of important works, most of which were religious in nature, emanated from the Seminary Press before it was amalgamated in 1755 with the state operated Castle Printing House ${ }^{14}$.

By the beginning of the nineteenth century, the other missionary societies that came to Indonesia, realizing they could not expect the government press to publish their materials, initiated printing operations. (The colonial policy was cautious not to antagonize the Moslems.) William Carey, a Baptist missionary who later was a printer in India, settled in Indonesia, and by 1800, published the Gospel of St. Matthere, but another Baptist missionary, Nathaniel Ward, and a British official, Sir Thomas Stamford Raffles, had a great deal to do with developing missionary publishing. Raffles had been to Bencoolen in Sumatra and, appalled by conditions there, wrote to his Baptist friends at Serampore (India) to send a missionary and press. When Raffles arrived in Bencoolen a second time in 1818, he brought Ward, along with Malay and English types. Raffles was superintendent of the Bencoolen press which was designed to educate Malay children with educational broadsheets. not religious tracts. The first works from that press were Malayan Miscellanies Vols. I and II in 1820, and Proceedings of the Agricultural Society of Sumatra Vol. I in $1821^{15}$. Raffles left to finish his work at Singapore; he returned to Bencoolen in late 1823 for a final visit to clear up his affairs and return to England, but before he reached England in 1824, Bencoolen and all of Sumatra passed to the Dutch. The press, which for some time suffered from a lack of paper, was closed and the missionaries departed ${ }^{16}$. De Graaf said Ward stayed on to print materials until $1826^{17}$.

Missionaries published elsewhere in Indonesia during the first three or four decades of the nineteenth century. Joseph Kam, a missionary sent by the Netherlands Mission Society, arrived in Java in 1815, and from there was sent to Maluccas where in 1819 he developed a press to print for the government. Others, such as Heijmering in Timor, Hardeland in Borneo and Mattern in Celebes, published during this same time ${ }^{18}$.

One of the most famous missionary printers in Indonesia was Dr. Walter Henry Medhurst, who arrived in 1822 from the Straits Settlements, where he had been involved with printing. Settling in Batavia, he set up a press at Parapattan, printing in Dutch, English, Chinese and Malay. Between 1823-1834, books and tracts, numbering 189, 294 copies, came of the Parapattan press with regularity. Medhurst generally had been given a free hand by the Netherland East India Company ${ }^{19}$ before leaving Batavia in 1842 to go to China which had opened its doors to missionaries. De Graaf did not know what became of the Parapattan press after Medhurst's departure ${ }^{20}$.

\section{China, Macao, Hong Kong:}

It is virtually impossible to relate early nineteenth century missionary printing activities in China without bringing in Macao and Hong Kong and even Malacca. The difficulty occurs because of the mobility of some of those presses and their printers. The 
dominating figures among these literary-minded missionaries, men such as Robert Morrison, William Milne, Walter H. Medhurst, Charles F. A. Gutzlaff and James Legge, who "devoted their energy to writing more than to preaching sermons,"21 had something to do with nearly every early nineteenth century missionary periodical started in China and Southeast Asia.

Morrison arrived in China first - in 1807 -, learned the Chinese language and eventually worked as an interpreter for the East India Company. He was a regular contributor to and assistant editor of the first English language newspaper in China, Canton Register ${ }^{22}$. At his own expense, Morrison brought a press from England and established the Albion Press in Macao (one of five presses in China then operated by foreigners ${ }^{23}$ from which he published the Anglo-Chinese Calendar, sermons and four numbers of a religious periodical started in 1833, The Evangelist and Miscellanea Sinica. The Evangelist's life was cut short when the Roman Catholic vicar-general at Macao, offended by its publication, had the use of the press forbidden. A letter from the Secretary of the Select Committee of the East India Company, dated June 22, 1833 , addressed to Morrison, accused him of having a press in his home on which "certain works are published contrary to the doctrines of the Roman Catholic Church, (1) and that as the use of a printing-press is prohibited in the Portuguese territories (2) by the royal authority, except under the restriction of a previous censorship, (3) His Excellency requests you may be directed to discontinue the employment of your press in this city. In conformity with these regulations of the Portuguese Government, I have received instruction from the President and Select Committee to desire (4) that you will suspend the issue of any further publications from the printing-press in your house at Macao."24

In his reply, Morrison said he realized his sermon was not comfortable to the Roman Catholic Church, but, he added, neither the printed sermon nor The Evangelist itself printed any attacks on that religion. Further, he said that it had been fully proved that Macao belonged to China, not Portugal, and that the East India Company had operated a press in Macao for nearly 20 years without pressures from the authorities. Despites his protestations, Morrison did submit to the authorities ${ }^{25}$.

Roman Catholic printers operated in Macao since the sixteenth century and they were there at about the time Morrison ran into trouble. The first newspaper in the territory, and perhaps the first Western language paper published on the China Coast, was $A$ Abelha da China (The Bee), edited by the superior of the Dominicans, Frey António de S. Gonzalo de Amarante. Issued weekly, this paper was a political party organ sponsored by the government. The second paper in Macao, Gazeta de Macau(1824-26), was also edited by a friar (Augustinian) and served as the organ of the Conservative Party which had taken over the government and the press on which $A$ Abelha was published ${ }^{26}$.

On the Chinese mainland, Christian missionaries were the innovators of printing, and periodical publication although the Chinese invented movable type 500 years before Gutenberg. Catholic missionaries published their first catechism in Chinese as early as $1584^{27}$; although they published many books and tracts, they did not get involved in periodical printing until the latter nineteenth century ${ }^{28}$. Again, it was the effort of the same Protestant missionaries, most of whom were affiliated with the London Missionary Society that produced the first periodicals in China. Part of the reason the Protestant missionaries depended so heavily upon the printed word 
in the early nineteenth century was because the Chinese did not allow the Gospel to be preached openly. In fact, at times, missionaries were not permitted in China. At first, missionaries were confined to Canton and Macao, but as Morrison's experience showed, the attitude of the Portuguese Roman Catholic mission towards the Protestant missionaries was hostile and jealous in the latter city ${ }^{29}$. Also, the literary persuasion of some of these missionaries was a stimulus to periodical publication. Some, such as Morrison and Milne, wanted to spread knowlege of the West to China and about China to the West (the reason for periodicals being in both Chinese and English); others, such as Gutzlaff, wanted to propagate or apologize for Western civilization.

According to The Chinese Repository, the East India Company press with printer arrived in China in 1814, thus ushering in modern printing. From that press, dictionaries, vocabularies, a translation of a novel and the Canton Miscellany (after 1831) were the principal works. By 1825 , a second press was on the scene and on it, after November 1827 , the first newspaper of the country, Canton Register, was published. A third press came to China in 1831, and two others were established in 1832. Thus, by 1832 , five English presses existed in China (two in Macao, three in Canton) ${ }^{30}$. As will be shown later, there would have been even more presses in China had the government exercised a different policy towards missionaries; after an Imperial Decree of 1812, making it illegal to publish Christian literature in China, some took their presses and went to more favorable climates such as Malacca, Singapore or Indonesia.

The first missionary operated periodicals in China were Nezes from All Nations (Canton, 1832) ${ }^{31}$, Tunghsiyank'ao Meiyueb T'ungchichuan (Eastern-Western Monthly Magazine, Canton, 1833) and The Chinese Repository (Canton, 1832). Eastern-Western Montbly Magazine was published by the German missionary, Charles F. A. Gutzlaff, with help from Morrison while it was in Canton (1833-37). After its transfer to Singapore in 1837 , Medhurst published it for a year. In 1834 , the periodical came under the umbrella of the Society for the Diffusion of Useful Knowledge, created by Gutzlaff and James Matheson, which had the grand aim of publishing a series of works dealing with the whole range of Western knowlege ${ }^{32}$. Gutzlaff was permitted to publish in China because he had good personal relationships with the Chinese authorities. Under his editorship, The Eastern-Western Monthly Magazine was an "apologia for Western civilization" 33 , about which Britton wrote: "Whereas Milne's magazine had been in main a periodical tract, and Medhurst's a periodical textbook, Gutzlaff's was a periodical apologia for Western civilization, designed to exhibit in an inoffensive manner the superiority of European culture and learning." 34

The most prestigious and long-lived periodical of these pioneers was The Chinese Repository. Actually The Repository grew out of desire by missionaries in Malacca to replace a periodical they had started there. Milne and Morrison had financed and published the Indo-Cbinese Gleaner (1817-22) in Malacca as an organ for the dissemination of knowledge of the Protestant mission and as a critical journal of sinology. When Milne died in 1822, the Gleaner died with him and Morrison continued to contribute articles about China to the number of English language periodicals and newspapers published in the Straits Settlements. An effort was made to replace the Gleaner in 1827 when the prospectus for a periodical, Indo-Chinese Repository, was issued in Malacca, but it did not materialize. When plans for the establishment of an 
American mission in China were developing in the early 1830s, Morrison urged that a press be part of the operation. An American firm donated a press and Gutzlaff offered for publication in a proposed new monthly, The Chinese Repository, his manuscript entitled, "Journal of a Voyage from Siam to Tientsin." The American missionary, Elijah Coleman Bridgman, became editor of the monthly with its first issue in May 1832, and remained in that position until the publication's death in December 1851. The Repository published in Canton most of the 20 years, except during the first Opium War when it was transferred to Macao (1839-44) and then to Hong Kong (1844-45) ${ }^{35}$.

Although Bridgman promised an unbiased periodical, The Repository actually was used at times to show the Western world the degraded nature of China and its need for Christianity ${ }^{36}$. Over 100 authors (mostly American missionaries and some merchants) contributed to The Repository during its lifetime, but most of the articles were written by five people - Robert Morrison and his son, J.R. Morrison, Bridgman, Gutzlaff and S.W. Williams ${ }^{37}$.

The periodical in 1836 had achieved a circulation of 515 (many of the foreign subscriptions going to other missionaries) but its death in 1851 ultimately resulted from a lack of subscribers. Malcolm also attributed increasing competition and a decline in interest on the part of China missionaries as causes for the Repository's demise. For example, in 1832 , there were only five Western presses and two English language newspapers in China, but by 1851,13 presses and five newspapers existed. As for the lack of interest, between 1807-44, of the 73 missionaries who had come to China, 33 contributed to The Repository. Of the 77 missionaries who had arrived in China between 1845-51, only three wrote for the monthly. Finally, the contacts among missionaries of Southeast Asia and China were not so great in the latter period and this diminished the interest shown in The Repository 38 . From 1851 to 1867 , no journal tried to minister to all Protestant missionary groups such as The Repository had, until the publication in 1867 of the Missionary Recorder (Foochow) by L.N. Wheeler. It lasted nine months and was followed in May 1868 by The Chinese Recorder and Missionary Journal which lapsed in 1872 and reappeared in 1874 from Shanghai where it published until at least World War II ${ }^{39}$.

After the Nanking Treaty of 1842 , when China was made more receptive to missionary activity, there was a flourishing of missionary printing activity in China, partly because some of the Protestant presses of Malacca, Penang, Singapore and Indonesia returned to the mainland. However, Britton reported that for 15 years after 1838, missionaries were not actively involved in publishing Chinese periodicals. Part of the reason was that as China was opened to missionaries, more emphasis was placed on opening chapels, schools and hospitals than on creating literary or printing works. Mission presses that were active concentrated on reprints and revisions more than on original productions ${ }^{40}$. Nevertheless, there was printing progress. In 1844, the American Presbyterians started a press in Macao which was transferred to Ningpo in 1845 and Shanghai in 1860. The American Baptist Board published in Canton until its presses were destroyed by fire in 1856; the press was reopened in Peking in 1868. Finally the American Methodists opened offices complete with a press in Foochow in 1861. James Legge moved the Malacca press to Hong Kong in 1843, and after 1853, had a hand in editing Hsia-Erb Kuan-chen (Chinese Serial), a Chinese monthly published at the London Missionary press in Hong Kong. The Cbinese Serial, started by Medhurst, was almost wholly secular with a considerable news section, and after 1855, a four page market/shipping supplement entitled Pu-kao Pien, was added. Because of other duties, Legge gave up the Serial in 1856; he returned to England in 1873, but his Chinese assistants and students carried 
on his newspaper work ${ }^{41}$. When the Chinese Serial was discontinued in 1856, a similar monthly which discussed the entire universe, Shanghai serial, was started by Alexander Wylie of the London Missionary Society; it lasted from January 1857 to February 1858.

Still other missionaries published periodicals and newspapers in China after 1842. Mission work spread up the coast to Shanghai and after 1860, entered the Yangtse River Valley and the interior. Marquis Lafayette Wood, John Fryer and Young Allen, for example, edited Hsin-pao, a Shanghai weekly between 1864-72; Daniel J. MacGowan, an American Baptist physician, started a semi-monthly, Chung-wai Hsin-pao, in Ningpo in 1854, and John MacGowan of the London Mission established the short-lived Chungwai Tsa-Chib (Miscellany Magazine) in Shanghai in $1862^{42}$. American missionary J.C. Beecher, a relative of Harriet Beecher Stowe, edited the Hong Kong Register and Daily Advertizer in 1860, and earlier, in 1842, the Rev. J. Lewis Shuck, an American Baptist missionary, was joint editor with James White of The Friend of China, published under various names and obviously in various places. Wright said it was one of the first newspapers in Hong Kong ${ }^{43}$, while King and Clarke said it published in Canton and Shanghai ${ }^{44}$. The most notable missionary editor of this period was the American, Young I. Allen. In 47 active years, he conducted a variety of Chinese newspapers and magazines and a translation service. For example, from 1867-71, he edited the Chinese issue of The North China Daily Newes and Herald; in 1868, he started Chiao-hui bsin-pao, a weekly miscellany of science, religion and news. Recognizing wider possibilities of a secular newspaper, Allen in 1875 changed the latter publication by adding more news and a new title, Wan-kuo Kung-pao (Globe Magzine) ${ }^{45}$. In 1891, Allen initiated an exclusively church newspaper, Chunghsi Chiao hui Pao. Of the giants among missionary publishers in the latter half of the nineteenth centruy (Charles Hillier, Alexander Wylie, Joseph Edkins, Timothy Richard), Allen stood out laboring "indefatigably" in the interest of the Christian mission $^{46}$.

Protestant missionary periodicals continued to appear with some regularity but most did not last more than a few years. Lowenthal reported that between 1868-80, 16 new Protestant religious periodicals were published, but by 1890 , only two of those remained ${ }^{47}$.

\section{Straits Settlements (Malacca, Penang, Singapore):}

From 1815 to about 1846, the Straits Settlements of Malacca, Penang and Singapore, as well as Indonesia as previously stated, were used by the London Missionary Society as locations for the printing of literature meant for China. The missionaries, needing another location because Christian preaching and writing were not openly permitted in China after the 1812 decree, chose Malacca first because it was halfway between India and China on a convenient water route and because it had a large Chinese population and no politcal restrictions ${ }^{48}$.

The periodicals that came off the Straits Settlements presses were among the earliest in East or Southeast Asia. Three months after William Milne came to Malacca on May 22, 1815, The Chinese Montbly Magazine (Ts-ashihshu Meiyueh T'ungchichuan) was started at the Anglo-Chinese Press, using printing paper and workmen skilled in xylographic printing and wood engraving that he brought with him from Canton. Considered the first Chinese periodical, Chinese Monthly Magazine was published in seven volumes of 574 pages between August 5, 1815 and 1822 when it stopped publishing shortly after Milne's death. 
A few issues were edited by Robert Morrison, Walter Henry Medhurst and Lian Ya-fah, the first Chinese printer in the Straits Settlements, but Milne was responsible for most numbers ${ }^{49}$.

Probably the best account of the inauguration of the periodical was given by Milne who wrote in 1819: "The first specimens were very imperfect, both as to composition and printing; but they were understood by persons who were in the habit of reading; and the editor hoped that a fuller acquaintance with the language, would enable him to improve the style. It was originally intended that this little publication should combine the diffusion of general knowledge with that of religion and morals, and include such notices of the public events of the day as should appear suited to awaken reflection and excite inquiry. To promote Christianity was to be its primary object; other things though they were to be treated in subordination to this, were not to be overlooked. Knowledge and science are the handmaids of religion, and may become the auxiliaries of virtue. To rouse the dormant powers of a people, whose mental energies are bound up by that dull and insipid monotony which has drawn out its uniform line over them to the length of more than twenty hundred years - will not be easy... The editor hopes, that he may in future have more leisure to attend to this branch of his work, and that the growing acquaintance of his brethren with the Chinese language will enable them to furnish useful papers on a variety of subjects; especially on those which have hitherto been but sparingly introduced. The size of the work has never yet exceeded that of a small tract, and it has been given away gratis. For about three years, five hundred copies were printed monthly, and circulated, by means of friends, correspondents, travellers, ships, etc., throughout all the Chinese settlements of the eastern Archipelago; also in Siam, Cochinchina, and part of China itself. At present (1819) a thousand copies are printed monthly. The demands and opportunities for circulation greatly increase, and it is likely that in three or four years two thousand copies will be an inadequate supply." 50

In November 1816, the Anglo-Chinese Press was supplemented with the arrival from Bengal of a printing press with English and Malay types, other printing equipment and six craftsmen, the latter of which distressed Milne initially who said he did not have enough work for them ${ }^{51}$. Milne used the extra help to publish English language books for the European community of the Straits Setlements, the result being, as one author noted, "Books - some of them of great importance - were poured forth from the press, periodicals were maintained, and vigorous methods taken to make Malacca the centre of Christiar propagandism on a large scale." 52 With the enlarged facilities and staff, Milne thought it justifiable to seek a superintendent for the press. His request was granted and Walter Medhurst arrived in June 1817 to assume the job. Medhurst, who later had his hand in printing throughout Southeast Asia ${ }^{53}$, stayed only until 1820 when he was ordained and left for Penang.

Later, to make the Anglo-Chinese Press profitable, the Malacca Mission went into commercial printing, handling the Malacca Observer and Chinese Chronicle and probably the Malacca Weekly Register (1839-40). The Observer, started by John Henry Moor, was printed at the mission press from September 1826 to October 1829 , when the fortnightly ran amiss of the authorities for commenting on government proceedings. Additionally, the Anglo-Chinese Press was responsible for publishing other mission periodicals, such as The Indo-Chinese Gleaner (1817-22) $)^{54}$, The Universal Gazette (T'ien hsia hsin wen, Chinese monthly, 1828-29) ${ }^{55}$, and The Periodical Miscellany and Juvenile Instructor (English month$1 \mathrm{y}, 1827)$. There had been a proposal to publish an Indo-Chinese Repository at the press but this did not happen ${ }^{56}$. 
After the first 15 years, publishing declined at the Anglo-Chinese Press. Although there was a continued demand for reprints of books, fewer new titles came off the press during its last decade. This resulted partly because agents who came to the press either died or left the missionary society before they mastered Malay or Chinese sufficiently to compose in the languages. In 1842, the Anglo-Chinese Press closed; its press and equipment were first shipped to Singapore and then in 1846, to Hong Kong.

Penang's second press was developed shortly after Medhurst arrived in mid-1820, bringing his personally-owned printing equipment with him from Malacca. The government gave him permission to operate the press but stipulated that "printing work required by Government will continue as before to be executed" on the government press. Agents of the London Missionary Society, Thomas Beighton and John Ince, who arrived in Penang in 1819, at first were delighted at the prospect of printing; however, later they were hesitant to allocate funds for more type. The press probably left Penang in 1821, when Medhurst wandered off to Batavia. Some years later, the Penang mission procured a small press and Malay type, and in 1834, Beighton and Ince began producing materials in Malay and Chinese for the mission's use ${ }^{57}$.

The important work relating to printing that was done at the Penang mission was that of the Rev. Samuel Dyer between 1827-35. Dyer was probably the first to introduce the art of Chinese type founding to the region. Until Dyer's movable Chinese type fonts were available, practically all Chinese printing performed at the various missions had been xylographic (from wooden blocks). In a letter to The Chinese Repository in 1827, Dyer explained the need for developing metal types for Chinese: "As the Archipelago is now opening extensively, and we are now wanting types in Combojan, Laos and so forth, and our opportunities are enlarging, ist is very desirable that we should bave a worker in steel on the spot; we could then proceed with punches of Chinese, Japanese, Cambojan, Laos etc.; and if we only had a person who understood the whole, we could employ native Chinese under him, and cut many punches at one rupee, or two shillings English each." 58 By 1842, Dyer had developed enough fonts of type to enable him to print on a limited scale. In China, Richard Cole, under the patronage of the Board of Missions of the Presbyterian Church, continued Dyer's work after the latter's death in $1843^{59}$.

Printing was introduced to Singapore by London Missionary Society personnel who arrived from Malacca in 1819. Claudius Henry Thomsen, when he came from Malacca in 1822 , brought a small press and workmen; in January of the following year, he, and another missionary, Samuel Milton, received permission to operate what became known as the Mission Press. Byrd suspected that printing was done on the Mission Press before permission was granted, possibly to print a Malay translation of a proclamation making gambling and opium farms illegal ${ }^{60}$. The Mission Press was more active than its Malacca counterpart in printing Malay books and tracts; it also catered for eight years without competition to commercial and governmental needs. For $6 \frac{1}{2}$ years, Singapore's first newspaper, Singapore Chronicle, was published at the Mission Press. Later, at least two Chinese newspaper, Tifang jith pao (Local News, 1845) and Jit Sheng (Rising Sun, 1858), were also published there.

Probably the most profilic Singapore printer of the period was Benjamin Keasberry, who came to the settlement as a missionary in mid-1839. Keasbery had become a London Missionary Society agent; when the Society closed its Singapore station in 1846, Keasberry chose to remain. The Mission Press equipment was shipped off, but the Society gave Keasberry types and equipment from the Penang and Malacca stations and a 
50 pound annual allowance. With these resources, Keasberry started a school and operated his press as a commercial venture to support the school, his family and his evangelization efforts. Later in January 1858, he published a Jawi quarterly journal, Chermin Mata, at the press. After Keasberry's death in 1875 , his work was continued by William Young until 1881, when the Presbyterian mission took over. The press equipment passed to Fraser and Neave and continued as Printers Ltd. until $1942^{61}$.

\section{Burma:}

The story of the first printing presses in Burma is part of the story of the American Baptist mission and particularly of American missionary, the Rev. Adoniram Judson. In August 1816, the Serampore missionaries gave the American Baptist Mission in Burma a new press and a "font of Burman types, together with the apparatus necessary for printing"62. Two months later, the Rev. George H. Hough, a trained printer, came to Rangoon to work the press. Judson, who was head of the mission, was worried because the press arrived before Hough came from Calcutta; he thought it would "probably be impossible to keep the press long in Rangoon. It will be ordered up to Java, as soon as the news of such a curiosity reaches the king's ears." ${ }^{63}$ The first work off the new press, published in 1817, was a Burmese language tract of Judson's on Christianity. A thousand copies were printed. Anderson wrote of the first printing in Burma: "It was not necessary to know much about Burmese to begin printing, and Hough was ready within a few months. All he had to do was match the odd-looking strings of circles. Adoniram had written with the appropriate circles in his fonts of Burmese type."64

Hough's press was taken back to Bengal until December 13, 1821, but even after its return to Rangoon - as late as August 1823 - nothing more was printed because of a shortage of types ${ }^{65}$. Operations were again stopped in 1824-26, and the press and type were removed to Calcutta, when England and Burma went to war ${ }^{66}$. In 1830, the Board sent Cephas Bennett, a practical printer, to Moulmein to develop a press that within seven years became the most important printing center in Burma. (For years, the only books published in Burma came from that press.) In a letter dated March 4, 1831, Judson wrote, "Brother Bennett works day and night at press; but he is unable to supply us; for the call is great at Mailmain and Tavoy, as well as here, and his types are very poor, and he has no efficient help" 67 . The following year, Oliver T. Cutter joined Bennett, but this arrangement did not last long as both men and their presses were transferred elsewhere. In January 1833, a Boston printer, Royal B. Hancock, came to Moulmein with two presses, a large quantity to type and materials for a type foundry; soon after, he established a spacious and substantial printing establishment. By 1844, the Moulmein press had seven presses and fonts of type for Burmese, Peguan and English; the Religious Herald in Burmese was printed there.

Still another missionary press was created at Tavoy in 1837 to meet the great demand for printed matter owing to the spread of the Gospel among the Karens. By 1844, the Tavoy press had two presses and type for Karen, Burmese and English. The Morning Star in Karen was published there. The press at Tavoy, headed by Bennett by $1846^{68}$, existed until 1855 when it was consolidated with that at Moulmein and placed under Bennett's supervision. Meanwhile, the former Moulmein superintendent, T. S. Ranney, went to Rangoon to start the private Pegu Press. Later, when Ranney left for the United States, the Missionary Union bought his press and Bennett removed the plant from Moulmein and united the two presses in Rangoon ${ }^{69}$. 


\section{Thailand:}

A medical missionary under American Missionary Association auspices is usually credited with introducing the modern printing press to Thailand ${ }^{70}$. Dan Beach Bradley hoped to make himself self sufficient by printing secular and religious works on his press after his arrival in Bankok in 1835. However, because Siamese type had to be cast in Bengal and there was a shortage of money at the time, the press lay idle for over a year until Charles Robinson solicited funds from the American Board of Commissioners for Foreign Mission and became the mission's printer. Robinson's stay in that position was short because "much of the type ... (Robinson) set fell into confusion"71; eventually he asked Bradley to relieve him as printer. As a result, Bradley's schedule became extremely hectic, to the extent that he had to reduce the number of his daily patients to 70 . Bradley, who had high aspirations and expectations, expanded to establish a book bindery and type foundry and trained his own printers. His standards were described as unrealistically high: "He once fired a resourceful printer for his indifference to the success of the printing establishment. A talented binder was also found among the unemployed when Bradley discovered that he was also an accomplished adulterer." 72

The physician-missionary proposed a newspaper for Bangkok in 1837, but because of lack of funds, it was not until 1844 that Thailand had its first newspaper, Bangkok Recorder $^{73}$. The paper lasted 16 months under Bradley's editorship before being abandoned until 1865, when it was re-established (by Bradley) in both Thai and English editions. Bradley was especially devoted to the Thai verson, Siamese Recorder (published every lunar month), because he aimed to use it to convert Thais; the English edition, Bangkok Recorder (published every two weeks), was kept to exchange for other English language newspapers of the Far East which provided him a news source. When the $R e^{-}$ corder was sued for libel and forced out of business for economic reasons, Bradley was not too unhappy for he had found that editing a newspaper was very taxing. After the demise of the Recorder, Bradley continued to write and edit for the Siam Weekly Monitor (started in 1867) and for the Rev. S. J. Smith's Bangkok Shipping List and Daily Advertiser (started in 1868).

Bradley printed over a million words a year trying to gain access to the minds and souls of Thais. Among his works were secular materials such as a dictionary, map of Bangkok, tract on strong drink and the first official Thai document printed on a Western press - a government edict against the importation of opium. One of his most important products was the Bangkok Calendar, an almanac done for the years 1858-73.

By 1850, the American Missionary Association (AMA) displayed a lack of confidence in its most experienced missionary (22 years in Thailand) by offering to sell the AMA presses to the Presbyterian mission without involving Bradley. The sale did not materialize, and instead, in the 1860s, the AMA purchased the press of the moribund Baptist mission to keep it from being purchased by Thais who would use it for "other than the Lord's work"74.

\section{South Asia}

India:

Portuguese Jesuits in 1556 introduced the first printing press to Goa although Goa was not the intended destination for that press. On a stopover in Goa, the patriarch-designate of Abyssinia was persuaded by the governor to remain; the result was neither he 
nor his press reached Abyssinia ${ }^{75}$. By October of that year, printing commenced in $\mathrm{Goa}^{76}$, with João de Bustamante serving as the first printer. However, by 1573 the Goa press ceased operations; a new press was set up in 1616 at Rachol, near Goa, and was worked until $1668^{77}$. Evidence exists of a third press in the New College of St. Paul in Goa in 1642 .

Printing spread throughout India during the 250 years after its introduction to Goa. Besides the Portuguese, at least the British, Spanish and Danish helped disseminate the technology of printing. For example, twenty years after the first Goa press was opened, a Spanish lay brother of the Jesuits, Goão Gonsalves, set up a press in Malabar and printed the first work in a local language - a Malayalam translation of Francis Xavier's Doutrina Christão. In extreme south India, in the village of Punikael near Tinnevelly, Father John de Faria started a press in 1587 and cast types of Tamil letters. Still other presses were developed at Vypicotta in 1602 and Ambalakad in 1679, but, according to Priolkar, the Jesuit missionaries after 1670 did not print much, partly because they had lost the zeal for missionary life ${ }^{78}$.

A London printer, Henry Hills, was sent to Bombay in 1674 after the first governor of Bombay requested of the East India Company a printer to print some sacred Brahmin scriptures. During his short stay, Hills published a few works but returned to England in "some disgrace" in 1679.

The Danish, who started Protestant missionary work in India, had a press in Tranquebar (in Madras State) ${ }^{80}$ in 1712, its aim being to produce the Bible in Tamil. Its printer, Bartholomew Ziegenbalg must have been very industrious, for by April 1713, 32 books in the Malabar language and 22 in Portuguese were published. By 1713, the Danish missionaries were manufacturing paper, and shortly after, they persuaded the king of Tanjore to establish a press there. The Tranquebar press flourished until 173981 .

A press started in India which had influences on other press development in South and Southeast Asia was the Baptist Mission Press, inaugurated at Mudnabatty in 1798, and moved to Serampore for political reasons in 1800. The Baptist Mission Press was instrumental in helping other nations open presses, sending trained printers and equipment to them. McMurtrie wrote that this press was the first and most important of a long line of mission presses in India which "exerted so great an influence on the spread of printing in that country"82. Responsible for the Serampore press was William Carey, a missionary who, when he arrived in Calcutta in 1795, had to carry on his evangelical work in secret because of East India Company restrictions. Carey requested a press from the London Missionary Society in 1798; the following year, four other missionaries were sent to assist Carey with his missionary and printing duties ${ }^{83}$. The first books off the Serampore press were a Bengali translation of the Gospel of St. Matthew, done by Carey in 1801, and Carey's Dialogues Intended To Facilitate the Acquiring of the Bengali Language in 1801. As with the Danish missionaries, Carey and his group were busy; in 1816, they founded the Calcutta Book society, and by 1818 , published at Serampore a Bengali monthly and a weekly, the first periodicals published in an Indian language ${ }^{84}$. The Serampore press was active until $1833^{85}$.

Numerous other presses were established throughout India during the early nineteenth century. For example, in 1812, the American Board of Commissioners for Foreign Missions sent five missionaries to Calcutta where they were denied admission. Two of these missionaries who ended up in Bombay developed a press by 1815-1786. As another example, in 1836, the American Baptist Missionary Society named the Rev. Nathan 
Brown and Cutter the first missionaries in Assam. They brought a printing press, 100 reams of paper and other materials to Sadiya where they published a book on the Assamese language in Roman characters. In 1837, they were joined by the Rev. Miles Bronson and an additional press he brought along. The mission and its press moved to Jaipur by 1838 , where during $1842-43$, Cutter had to dismantle the press and hide it during an insurgence ${ }^{87}$.

Other mission presses existed at: Kottayam, 1824; Bellary, London Missionary Society, 1810, and Madras Auxiliary Bible Society, 1826; Bangalore, Wesleyan Mission Press, 1844; Allahabad, Presbyterian Mission Press, 1840; Benares, English Church Missionary Society, 1818-19; Calicut, Wesleyan or Methodist press, 1791; Madras, Madras Auxiliary Bible Society, 1820; Cuttack, Orissa Mission Press, 1839; Magercoil, 1827; Pondicherry, 1784; Surat, Bombay Auxiliary of the British and Foreign Bible Society (BFBS), 1821, and Tanjore, BFBS, $1808^{88}$.

Missionary printers, as has been indicated, were not always welcomed or tolerated by the authorities in India. The British rulers, for instance, feared that missionary activity might endanger the stability of British rule. Presses that were allowed to operate, often were placed in areas where the authorities could easily control them.

\section{Ceylon:}

It was the same Dutch governor who encouraged printing in Indonesia, Baron Imhoff, who implored the Dutch East India Company to provide a press for the Dutch missionaries in Ceylon. The press arrived in 1736, and the following year, the first book, Singaleesch Gebeede-Boek (Singhalese Prayer Book) appeared ${ }^{89}$. The Dutch East India Company maintained a regular output of printing between 1737 and 1760 ; the scale of the production was reduced between 1760 and 1790 .

After the British took over Ceylon in 1796, the London Missionary Society and other missionary groups sent agents to Colombo and elsewhere on the island. Presses soon sprang up at Colombo, Wesleyan Mission Press, 1815; Cotta, Church Missionary Society, 1822; Kandy, Baptist Mission Press, at least by 1841; Jaffna, Wesleyan Church Missions Press, 1825, and Nellore, Church Missionaries, 1834 (at least two presses existed at the Nellore mission) $)^{90}$.

By mid-nineteenth century, many of these missionary presses and the missionaries themselves were responsible for the production of most of Ceylon's literary periodicals. Between 1837-49, for example, of those connected with literary periodicals, 13 were clergy or missionaries, four were civilians, two each were merchants and "native gentlemen" and one was a "legal practitioner"\%1. The first literary magazine in Ceylon, Religious and Theological Magazine, appeared in Colombo in 1833. It was the work of the Rev. B. Bailey, who toiled without assistance for two years until the magazine was doomed with his retirement in October 1834. The magazine's main feature was a series of "very readable and instructive essays, as well as a succession of Bible Biographies"92.

Wesleyan missionaries founded The Friend (Colombo, 1837), the second literary magazine which had the far-fetched aims of: "so far as our very limited influence extends, to restore the world to its original purity" and "to turn the World upside down"93. This English language periodical lasted a decade before those who were responsible for its publication left Ceylon. The Wesleyan missionaries also initiated Lanka Nidhana (Lamp of 
Ceylon, Colombo, 1840), a Sinhalese language periodical made up mostly of religious "extracts" and given free to villagers.

Still other missionary originated literary publications included: Protestant Vindicator(Colombo, 1839), created to counter Roman Catholic propaganda; Ceylon Magazine (Colombo 1840), which included the Rev. Bailey among its contributors; The Investigator (Kandy, 1841), started by a Baptist missionary who said he wanted to promote truth and the public good, but according to one source, fel far short of that aim, instead, cavilling at and calling into "question the proceedings of all those who were not exactly of his way of thinking94; and Morning Star (Jaffna, 1842), issued from the American Mission Press. Most of these periodicals did not live long; in fact, in 1849, only one of the above survived.

\section{Pakistan:}

Missionaries were responsible for the first printing in the Punjab. By December 1835 , the Revs. John Newton and James Wilson, Presbyterian missionaries, had brought a press to Ludhiana. The following year, an Indian compositor from the Baptist Mission Press in Calcutta taught Newton the mechanics of printing, and in that summer, the first product of the Ludhiana Mission Press appeared under the title, $A$ Sermon for the Whole World. From 1836 to at least 1841, a four page, Persian language newspaper, Lodiana $A k b b a r$, was published on the press. The early issues of the paper, the first in the Panjab, were in manuscript. Later, in 1873, the Ludhiana Mission started a weekly in Persian and Urdu, Noar Ufshan. The press had a series of misfortunes, including a fire in 1845; the mission itself was burned by Sepoy mutineers in 1857. Despite these setbacks, the press made comebacks and was the chief source of Christian literatur for all missionary organizations in the North-West Provinces..$^{95}$.

\section{Conclusion}

A number of conclusions can be reached concerning the role of missionaries in the development of Asian printing and journalism. Among them are:

1. Both colonial administrators and church officials recognized the importance of the printing press in achieving their goals. In some instances, requests for printing equipment and presses emanated not just from the missionaries, but also from Dutch and British East India Company officials. However, there were instances where the colonial or church authorities did not sanction printing or kept it under close scrutiny. In the case of China, local officials feared the impact of the missionaries and printing, and at times, banned or limited the activities of both.

2. As would be expected, the presses were used primarily to proselytize for Christianity. However, the introduction of printing also helped develop written Asian languages with the publication of grammars and vocabularies and with the founding of new type fonts to meet the requirements of the diversified language structure of Asia. Unfortunately, missionary presses were also utilized to promote Western and Christian superiority and Asian inferiority. Some of this occurred in the periodicals the missionaries sponsored, although many of these magazines and newspapers were meant to act as cultural exchange agents. 
3. The periodicals created by the missionaries were the forerunners of modern Asian journalism. Before the arrival of Christianity, periodicals did not exist in Burma or Thailand and only a limited few published in other countries. The periodicals acted as outlets for the intellectual communities of Asia; a negative aspect was that they were for the colonists and not the native populations, many of which had low literacy rates and few writers. Also, the periodical press acted as a commnunication network as missionaries exchanged their publications and learned from each other.

4. Some of the individuals who printed during the missionary press period were extremely dedicated to the use of printing. Some, such as Medhurst, wandered the region, in the process, developing the first presses in some of the countries where they stopped; others, such as Bradley in Thailand, remained in one place for the most part, publishing various types of materials for sustained periods of time. As was indicated, many missionaries devoted their entire lives to the printing profession, in the case of Young Allen, 47 years. In some instances, the press was so dependent upon the services of one individual that upon his death or transfer, the press would falter.

5. At different times, key printing centers arose in Asia. Goa and Macao acted in that capacity in the sixteenth century and Serampore, Macao and Malacca in the nineteenth century. In these cities, printers were trained, equipment was collected and type fonts were invented and cast, to be put at the disposal of missions in other nations that requested these services.

\section{Notes}

${ }^{1}$ East and Southeast Asia are treated together because some of the periodicals of the Protestant printer missionaries of the early nineteenth century were printed at various times in both regions.

2 Diego Pacheco, "Diogo de Mesquita, S.J. and the Jesuit Mission Press", Monumenta Nipponica, 26 (1971): 3/4, pp. 431-443 See aösp. Shigetomo Koda, "Notes sur la presse jésuite au Japon et plus spécialement sur les livres imprimés en caractères japonais." "Monumenta Nipponica, July 1939, p. 42; B. H. Chamberlain, "A Review of Mr. Satow's Monograph on 'The Jesuit Mission Press in Japan, 1591-1610," Translations of the Asiatic Society of Japan, 1889, pp. 91-100.

Some controversy exists concerning the dates of the first printing from movable type in Japan. Pacheco's dates are more accurate because he used recent primary data on the topic. Chibbett claimed the Portuguese mission was dispatched to Europe in 1582, not 1586, and returned in 1590 with a press. The first book from the Jesuit Mission Press was published in 1591, the last in 1611 when the press was transferred to Macao, according to Chibbett. He also believed the Jesuit press was acquired in Lisbon or Rome, reached Japan via Lisbon, Goa and Macao, and was set up first at Kazusa, then Amakusa, before finally settling in Nagasaky between 1598 and 1600. David Chibbett, The History ofJapanese Printing and Book Illustration, Tokyo: Kondansha International Ltd., 1877.

${ }^{3}$ Chibbett, op. cit., p. 61

4 lbid., p. 72.

5 Ibid., p. 77.

6 See, Kisaburo Kawabe, The Press and Politics in Japan, Chicaco: University of Chicago Press, 1921, p. 41; Kanesada Hanazono, The Development of Japanese Joumalism, Tokyo: The Tokyo Nichi-Niche, 1934. Kawabe differs from Hanazono, saying that the paper was the product of a Dutchman named Berry who came to Yokohama as a missionary. See also, James I. Seder, "The Japanese Religious Press," The Missionary Reviewe of the World, July 1893, p. 492. 
7 Valenzuela does not believe the first Philippine press came from Japan because he said the press was too new there and the types were different. Although Macao had printing before 1590. Valenzuela said the missionaries did not print books there after 1590 . His belief was that the first Philippine press came form Goa. Jesus Valenzuela, History ofJournalism in the Philippine Islands, Manila: Published by author, 1933, pp. 4-5.

8 Ibid., pp. 8-9.

9 Ibid., p. 9.

10 Ibid., pp. 36, 71.

11 Douglas C. McMurtrie, Memorandum on the History of Printing in the Dutch East Indies, Chicago: Privately printed, 1935.

12 H. J. de Graaf, The Spread of Printing: Indonesia, Amsterdam: Vangendt and Co., 1969, pp. 11-12. De Graaf reported that the effort to have a printing establishment was renewed in 1659 , and that shortly after that date, Kornelis Pijl printed a tijdboek (Timebook), which might have been an attempt at newsletter.

13 The Supreme Government ordered that better printing equipment be sent from Holland which arrived in 1668. "When, on 14 March 1668, the good news was received in Batavia that Damiral Cornelis Speelman, after a violent struggle, had concluded a treaty of peace with the prince of Macassar, the Supreme Government ordered the immdiate printing of the peace terms, and thus the oldest surviving printed document to come down to us first saw the light." De Graaf, op. cit., p. 13.

14 Ibid., p. 23.

15 C. E. Wurtzburg, "The Baptist Mission Press at Bencoolen," Journal of the Malayan Branch of the Royal Asiatic Society, Vol. 23, Part 3 (1950), pp. 136-142. Wurtzburg said botanist Dr. W. Jack probably edited Miscellanies. According to him, the third volume of Miscellanies, second volume of Proceedings and a Malay version of Scriptures which Raffles planned, did not appear, probably because an epidemic hit Bencoolen in 1822, killing Dr. Jack, among others.

16 Ibid., p. 139.

17 De Graaf, op. cit., p. 31.

18 Ibid.

19 Somewhat unusual since in 1831, when the missionary, Brückner, brought his Javanese Nere Testament printed at the Baptist press in Serampore) to Indonesia, the whole stock was confiscated by the government. Ibid., p. 51 .

20 Ibid.

${ }^{21}$ Lin Yutang, A History of the Press and Public Opinion in China, Shanghai: Kelly and Walsh Ltd., 1936, p. 78.

22 When James Matheson founded the weekly Register in 1827, he sought the help of Morrison who agreed as long as he had full liberty to express his opinions on moral and religious subjects.

23 The Chinese Respository, June 1833, pp. 92-93.

24 Marshall Broomhall, Robert Morrison: A Master-Builder, New York: George H. Doran Co. 1924, pp.178-179.

25 Actually, he had very little choice. If he refused, he would have been forced to resign from the East India Company and face deportation from Macao. His anguish over the incident was reflected in articles he wrote in the Canton Register and in a letter to the Religious Tract Society in London, in which he said, "The continuance of the press in Canton is very precarious. There is no place nearer than Malacca and Singapore where it can work freely." Ibid., p. 182.

26 Frank H. H. King and Prescott Clarke, A Research Guide to China-Coast Newspapers 1822-1922, Cambridge: East Asian Research Center, Harvard University, 1965, p. 34. 
${ }^{27}$ Rudolf Lowenthal, The Religious Periodical Press in China, Peking: The Synodal Commission in China, 1940, p. 5.

28 Roswell Britton, The Chinese Periodical Press 1800-1912. Shanghai: Kelly and Walsh Ltd., 1933, p. 17. Lowenthal wrote that the first Catholic periodical in China did not appear until 1892 when the scientific Jesuit Bulletin des observations meteorologiques was published at Zikawei. The first Catholix religious periodical in all of the Far East (except the Philippines) was the Hong Kong Catholic Register, started in 1877 by Bishop Raimondi. By 1939, despite its slow start, the Catholic press had periodicals in China. Lowenthal has documented other religious presses of China and has shown that Buddhist, Taoist and Confucian magazines did not appear in China until 1912, 1917 and 1913, respectively. Lowenthal, op. cit., pp. 5, 139, 168, 191.

29 Elizabeth L. Malcolm, "The Cbinese Repository and Western Literature in China 1800 to 1850," Modern Asian Studies, $7: 2$ (1973), p. 165.

30 "Introductory Remarks," The Chinese Repository, May 1834, pp. 1-9; see, The Chinese Repository, May 1834, pp. 43-44.

31 Lowenthal, op. cit., p. 77. Another source said this periodical, appearing under the Chinese name, Ko-kuo Hsiao-bsi, was started in Canton in 1838 by Medhurst, with help from Charles Batten Hillier. It contained foreingn news and a local price current and only survived a few issues. Chen Mong Hock, The Early Chinese Newspapers of Singapore 1881-1912, Singapore: University of Malaya Press, 1967, p. 25.

32 Chen, op. cit., p. 24. For discussion of publications of this Society, see, "Publications of the Society for the Diffusion of Useful Knowledge," The Chinese Repository, November 1833, p. 329.

33 Lin Yutang, op. cit., pp. 82-83.

34 Britton, op. cit., p. 22 .

35 Most of this history of the Repository comes from the author's reading of The Chinese Repository and from Malcolm, op. cit.

36 Malcolm wrote that the missionaries took a very dogmatic stand as to the right of Christianity. Both missionaries and merchants united in their goal to see China thrown open to Western penetration, and according to Malcolm, in spite of their undoubted knowledge and experience, these individuals could hardly be regarded as reliable sources of information on China. The Repository, she concluded, was a wealth of detailed factual information, some of which was prejudiced. Malcolm, op. cit., pp. 169-170. This author concurs. As just one example, in an article in the October 1834 Repository on the need for metallic type development in Chinese, a correspondent wrote: "We are apprehensive, however, that 'the Chinese have neither the genius in the head nor the power in the fingers' to give complete success to the plan." King and Clarke reported that the foreign editors in China made harsh judgments of the Chinese in their writings. They quoted James Matheson, who wrote: "The Chinese - a people characterized by a marvelous degree of imbecility, avarice, conceit, and obstinacy." Some of these Western attitudes and judgments were based on the Protestant belief that those living without the word of God were bound to a life of evil. King and Clarke, op. cit., p. 6.

37 Nearly all missionaries in the country contributed articles. Malcolm, op. cit.

38 Ibid.

39 Lowenthal, op. cit., p. 77. See, Kenneth Scott Latourette, A History of Christian Missions in China, New York: Russell and Russell, 1929, p. 437.

40 Britton, op. cit., p. 34.

41 Ibid., p. 35.

42 lbid., pp. 51-52. Britton provides added information on specific missionary editors of the latter 1800 s, such as John Glasgow Kerr, who started at least three periodicals between 1865 and $1880 ;$ John Chalmers; J.M.W. Farnham, creator or editor of three magazines between 1871 and 
1915; Mrs. George Fitch; Thomas Barclay; J. C. Gibson; N. J. Plumb; William Muirhead and John Shaw Burden. Ibid., pp. 56-60.

43 Arnold Wright, Trentieth Century Impressions of Hong Kong, Shanghai, and Other Treaty Ports of China, London: Lloyd's Greater Britain Publishing Co. Ltd., 1908, p. 343.

44 King and Clarke, op. cit., pp. 49-50.

45 The newspaper stopped in April 1883 and resumed in 1889 as a monthly. The Chinese title remained the same but the English name was changed to $A$ Review of the Times. Allen was still editor but the business management of the newspaper was under the new Society for the Diffusion of Christian and General Knowledge among the Chinese, later renamed the Christian Literature Society. Wan-kuo Kung-pao published until 1907, a few months after Allen's death. Britton, op. cit., p. 54.

46 Lin Yutang, op. cit., p. 84

47 Lowenthal, op. cit., p. 78. Lowenthal reported that no new Protestant periodicals were started between 1880 and 1885; ten between 1886-90. The total Protestant periodicals in China between 1815 and 1937, according to Lowenthal, was 540; of this total, 258 existed in 1939 when he conducted his survey. Others have written on the Protestant press of the latter nineteenth century. Latourette reported "a good many periodicals" edited by missionaries, as many as 13 in Chinese published in 1890. Latourette, op. cit., p. 436. See also, Archibald R. Colquhoun, "The Chinese Press of To-Day" North American Review, January 1906, pp. 97-104.

48 Cecil K. Byrd, Early Printing in the Straits Settlements, 1806-1858, Singapore: National Library, 1970, p. 9; see also, Britton, op. cit., pp. 17-18.

49 China Handbook 1937-1943, pp. 696-711.

50 "The Chinese Magazine," The Chinese Repository, September 1833, pp. 235-236.

51 Byrd, op. cit., p. 10.

52 William John Townsend, Robert Morrison: The Pioneer of Chinese Mission, New York: Fleming H. Revell, n.d., p. 85.

53 During his career, Medhurst helped edit A Monthly Record of Important Selections (T'ehhsuan Tsoyao Meiyueh Chiwen) in Batavia, 1823-26; The News of All Nations; Chinese Monthly Magazine and Universal Gazette, among others, Lin Yutang, op. cit., p. 82.

54 Milne started the Gleaner in 1817 after opening the Anglo-Chinese College, and published it as a quarterly until his death in April 1822. The Chinese Repository, August 1833, pp. 186-187. In a letter to Morrison, dated November 26, 1819, Milne said of the Gleaner: "It is not learned enough for the learned - it is not religious enough for the religious - it is not worldly enough for the worldly."

55 Edited by Samuel Kidd, the third principal of the Anglo-Chinese College. The Universal Gazette contained mainly news of Europe and China. Chen, op. cit, p. 6.

56 The prospectus for this periodical appeared in "European Periodicals Beyond the Ganges," The Chinese Repository, August 1836, pp. 149-150. That same article assumed that the Periodical Miscellany and Juvenile Instructor was the replacement of the Indo-Chinese Repository because it carried the same prospectus. See also, Asiatic Journal, August 1827, pp. 250-251, which reported it had learned about a proposal to start a Chinese language newspaper in Malacca.

57 Byrd, op. cit., p. 5.

58 “Chinese Printing," The Chinese Repository, February 1833, pp. 417-418.

59 The Chinese Repository, May 1851 pp. 281-285. Also, The Chinese Repository, March 1845, pp. $124-$ 129. Other issues of The Chinese Repository carried articles on metallic types in Chinese. In the October 1834 issue (pp. 246-252), an article appeared on "Estimate of the proportionate expense of Xylography, Lithography, and Typography, as applied to Chinese printing; view of the advantages and disadvantages of each"; the March 1835 issue (pp. 528-533) reported on casting of fonts of Chinese types by steel punches in Paris; the May 1850 number (pp. 247-253) dis- 
cussed Chinese use of movable type. The success of the missionaries' efforts in type founding was mentioned in the December 1844 Repository $6 \mathrm{pp} .651-652)$ : "Numerous efforts have been made to introduce among the Chinese the art of printing with metallic type, most of these have been made by Protestant missionaries, and they have been attended with so much success, that we anticipate seeing, at no distant day, the cumbrous and imperfect mode of blockprinting giving way to the neater, cheaper, and more expeditious methods of more civilized lands."

60 Byrd, op. cit., p. 14. Byrd reported that Milton had gone to India in December 1822 to obtain printing equipment, which caused consternation in London because the London Missionary Society had not authorized the purchase. Milton was dismissed from the Society and the proprietary rights of the press were clouded for 20 years. The press operated from the Singapore Institution with first Milton and then Thomsen in charge for a few years. On May 10, 1834, Thomsen, who had also been dismissed from the Society, sold the presses, buildings and some land to the American Board of Commissioners for Foreign Missions for 1.500 Dollars. It is not known how Thomsen obtained proprietary rights to the press, but the Society disputed his ownership. For eight years, the Society negotiated with the American Board concerning the bargain purchases. When the American Board left Singapore in 1843, it gave the press and land to the Society without charge.

${ }^{61}$ Byrd, op. cit.

62 Dennis Rhodes, The Spread of Printing: India, Pakistan, Ceylon, Burma and Thailand, Amsterdam: Vangendt and Company, 1969, p. 81.

63 Courtney Anderson, To the Golden Shore: The Life of Adoniram Judson, Boston: Little, Brown and Co., 1956, p. 194. Another source differed, saying Hough brought the press with him. Trager wrote that Judson welcomed Hough because he "understands the printing business" and brought as small press which would be used to distribute, in Judson's words, "a bit of bread to the starving, perishing Burmans around us." Helen Trager, Burma Through Alien Eyes: Missionary Views of the Burmese in the Nineteenth Century, New York: Frederick, A. Praeger, 1966, p. 23.

64 Anderson, op. cit., p. 195.

65 Rhodes, op. cit., p. 82.

${ }^{66}$ Arnold Wright, Twentieth Century Impressions of Burma: Its History, People, Commerce, Industries and Resources, London: Lloyd's Greater Britain Publishing Co. Ltd., 1910, p. 137.

${ }^{67}$ Rhodes, op. cit., pp. 83-84.

68 Ibid., p. 87. Wright disagreed, saying Bennett headed the Tavoy press in 1837. Wright, op. cit., p. 137.

69 Wright, op. cit., p. 137.

70 Rhodes credited the American Baptist Mission with doing the first printing in Bangkok. The Rev. John Taylor Jones, formerly of Rangoon, prepared the Gospel of St. Matthew for the press in 1835. However, he had to take this and other ecclesiastical works to Singapore to have them published. A Rev. Davenport, a trained United States printer, arrived in Bangkok in 1836 and set up a press at that time. Rhodes said Jones obtained materials from Dyer in Penang for a type foundry. A second press was added to the property of the mission in Bangkok in December 1838. Rhodes, op. cit., p. 93. Mitchell said there is some evidence that the first printing was done by the French Catholic Mission in 1622 at the capital, Ayuthia, north of Bangkok. Mitchell, quoting from Bradley's personal journal, said Robinson printed in Bangkok before Bradley's arrival (and not after) and left Bangkok for reasons of family health. John D. Mitchell, "Thailand," in John A. Lent, The Asian Nevespapers'Reluctant Revolution, Ames: Iowa State University Press, 1971, p. 210.

${ }^{71}$ Donald C. Lord, Mo Bradley and Thailand, Grand Rapids: Eerdmans Publishing Co., 1969, pp. 93-95. 
Wright wrote that Bradley started a small newspaper in Siamese in 1844 , but because of transportation problems the paper folded after a struggling year. He implied that the Bangkok Recorder was a seond newspaper founded by the Rev. N.A. MacDonald of the American Presbyterian Mission, and afterwards conducted by Bradley. This paper's life was cut short by a lawsuit. Arnold Wright, ed. Twentieth Century Impressions of Siam: Its History, People, Commerce, Industries, and Resources, London: Lloyd's Greater Britain Publishing Co. Ltd., 1908, p. 293.

74 Lord, op. cit., p. 97.

75 Anant Kakba Priolkar, The Printing Press in India: Its Beginnings and Early Development, Bombay: Marathi Samsnodhana Mandala, 1958, pp. 3-4.

76 There are some differences concerning the first book published at Goa. Priolkar said the first was Doutrina Christão, a catechism written by St. Francis Xavier and published in 1557, while Rhodes and Primrose reported that Conclusões. a work by Antonio de Quadros, published in 1556, deserves the honor. Rhodes and Primrose listed the catechism as the second book. Priolkar's claim is given more credence by this author because he indicated he worked with primary documents. Priolkar, op. cit., p. 4; Rhodes, op. cit., p. 11; J. B. Primrose, "The First Press in India and Its Printers." The Library, December 1939, p. 243. For conflicting dates on the first press, compare Primrose with Leo Proserpio, "The First Printing-Presses in India," The Neze Revieze, October 1935, pp. 321-330.

77 Again, there is some controversy about the length of life of the first Goa press. Priolkar said it lasted until at least 1588 , claiming that by that date, 13 pieces of literature had been published. Priolkar, op. cit., p. 14. Shaw said the Goan press published the first works in Marathi, the first of which was Doutrina Christam in 1622. Graham Shaw, "The Tanjore 'Aesop' in the Context of Early Marathi Printing, The Library, Sept. 1978, p. 207.

78 Priolkar, op. cit., p. 25.

79 J. B. Primrose, "A London Printer's Visit to India in the 17th Century," The Library, June 1939, pp. 110-104.

80 In Madras, German Lutheran missionaries, Johann Philipp Fabricius and Christian Breithaupt, published grammars, proceedings of the medical society, dictionaries and religion books at the Church Mission Press in the 1770s.

81 Priolkar, op. cit., pp. 36, 46; Rhodes, op. cit., p. 17.

82 Douglas C. McMurtrie, "Early Mission Printing Presses in India," The Indian Printer and Stationer, Special New Year Number, 1933, pp. 1-3.

83 Rhodes, op. cit., p. 29.

84 Ibid. Natarajan just reported that by 1823 , the Serampore missionaries had a Bengali newspaper, S. Natarajan, A History of the Press in India, New York: Asia Publishing House, 1962, p. 29.

85 McMurtrie, op. cit.

86 Priolkar, op. cit., p. 79.

87 Rhodes, op. cit., pp. 61-62.

88 Ibid., pp. 48-59, McMurtrie, op. cit.

89 Douglas C. McMurtrie, "Memorandum on the First Printing in Ceylon with a Bibliography of Ceylonese Imprints of 1737-1760," Chicago: Privately printed, 1931; Rhodes, op. cit., p. 67.

90 Rhodes, op. cit., pp. 76-78.

91 "The Periodical Literature of Ceylon," The Calcutta Review, January 1849, p. 4.

92 Ibid, p. 5.

93 Ibid., p. 6. 
94 Ibid., p. 26.

95 Graham W. Shaw, "The First Printing Press in the Punjab," The Library Chronicle, Winter 1979, pp. 159-179.

\section{ZUSAMMENFASSUNG}

Fast jeder, der sich mit der Geschichte des Druckereiwesens beschäftigt, weiß, daß hier enge Bande zwischen Christentum und den frühen Druckereien bestehen. Gutenbergs erster Druck war eine Bibel, und viele Erstdrucke im christlichen Westen galten religiösen Büchern und Traktaten. Was dabei allerdings verborgen blieb, ist die Bedeutung des Christentums für den Beginn des Druckerei- und Pressewesens in vielen nichtchristlichen Ländern. Dafür ist Asien ein Beispiel. Katholische und evangelische Missionare haben in einem Land nach dem anderen als erste Druckereien errichtet und Zeitschriften begonnen. Katholische Missionare haben schon im 17. Jahrhundert, zumindest in Macao, Japan, den Philippinen und Indien gedruckt und verlegt. Protestantische Missionare der Vereinigten Staaten und Europas folgten später und begannen erste Druckereien oder Zeitschriften zumindest in Burma, Thailand, Malaya, Singapore, Indonesien und Teilen von China. Die Namen von Missionaren stehen weithin für den Journalismus in Asien im 19. Jahrhundert. Eine Dokumentation über Missionsdruckereien in Ost- und Südost- sowie Südasien ergibt ein vielfältiges Bild.

Eine der ersten Druckereien, die von Europa nach Asien gebracht wurden, war in Japan jene, die der portugiesische Jesuit Diogo de Mesquita während eines Europaaufenthaltes 1586 für Nagasaki erwarb und die dort bis zu seinem Tode am 4.11.1614 mit japanischen Lettern in Betrieb war, dann aber nach Macao verlegt wurde. Der Block-Druck bestand in Japan schon wenigstens seit $764 \mathrm{v}$. Chr. und beherrschte das Bild des Druckereiwesens bis zum letzten Jahrzehnt des 16. Jahrhunderts. Schon vor Ankunft der Jesuiten war dieses Druckverfahren die Domäne der religiösen Autoritäten: die Drucke wurden von buddhistischen Mönchen in deren Tempeln hergestellt. Der Druck mit beweglichen Lettern wurde nach der Darstellung einer Quelle Ende des 16. Jahrhunderts gleichzeitig aus Portugal und Korea eingeführt. Diese Druckereien wurden zum Teil in buddhistischen Tempeln betrieben. Eine der ersten periodischen Veröffentlichungen, die 1867 gegründete „Bankoku Shimbun” (Universalnachrichten) war die dritte Gründung einer Zeitung in Japan und die erste eines Ausländers, des englischen Kaplans Backworth Baily.

Auf den Philippinen begannen die Dominikaner mit der ersten Druckerei, in der als erstes Werk 1593 eine „Doctrina Christiana” veröffentlicht wurde. 1606 folgten die Franziskaner mit der Veröffentlichung u.a. von Grammatiken und Lexiken, und 1611 kauften die Augustiner eine Druckerei, die sie 1622 an die Jesuiten weiterverkauften. In der Zeit von 1593 bis zum 19. Jahrhundert läßt sich auf den Philippinen die Veröffentlichung von 541 Buchtiteln nachweisen. Im Februar 1861 erschien als erste religiöse Zeitschrift „El Católico Filipino” und 1876 folgte das „Boletin Ecclesiastico del Arzobispado de Manila". Allgemeine Zeitschriften gab es in Manila bereits seit 1811.

Der Beginn der Druckereien in Indonesien ist nicht ganz so eindeutig. Einmal heißt es, daß 1624 die Niederländische Reformierte Kirche bereits eine Druckerei besaß, ihr aber geschulte Drucker fehlten. Dann aber wird der Beginn einer erfolgreichen ersten Missionsdruckerei erst für 1667 angesetzt. Sicher wurde eine Druckerei 1743 vom Generalgouverneur, Baron von Imhoff, zur Verbreitung des Christentums eingeführt.

Für China, Macao und Hongkong sind vor allem Persönlichkeiten zu nennen, die eine gewisse Mobilität aufweisen und ihre missionarische Aufgabe mehr im Schreiben als im Predigen sahen. So brachte Robert Morrison zu Beginn des 19. Jahrhunderts eine Druckerei von England nach 
Macao, wo er die „Albion Press” begann, die u.a. seit 1833 „The Evangelist and Miscellanea Sinica" veröffentlichte. Wegen Auseinandersetzungen mit dem katholischen Generalvikar von Macao beendete er dort seine Tätigkeit. Katholische Druckereien gab es in Macao bereits seit dem 16. Jahrhundert, und als erste Zeitschrift erschien wöchentlich von den Dominikanern „A A belha da China", wahrscheinlich die erste periodische Veröffentlichung in westlicher Sprache an der chinesischen Küste. Auf dem chinesischen Festland veröffentlichten katholische Missionare 1584 ihren ersten Katechismus, allerdings erschienen Zeitschriften erst im 19. Jahrhundert. Nach dem Frieden von Nanking 1842 begann eine neue Blüte des missionarischen Druckwesens in China, Macao und Hongkong.

Die Londoner Missionsgesellchaft gebrauchte zwischen 1815 und 1846 als ihre Hauptbasis für chinesische Literatur die Gebiete von Malacca, Penang und Singapore ebenso wie Indonesien. Am 22. Mai 1815 begann in Malacca ein chinesisches Monatsmagazin, das als erste periodische Veröffentlichung in chinesischer Sprache angesehen wird (1815-1822). Die anglo-chinesische Druckerei, in der dieses Blatt erschien, wurde später kommerziell ausgebaut und veröffentlichte auch allgemeine Zeitschriften. Als die Druckerei 1842 geschlossen wurde, gingen ihre Maschinen zunächst nach Singapur und dann 1846 nach Hongkong. In Singapur wurde das Druckwesen durch Personal der Londoner Missionsgesellschaft 1820 eingeführt.

In Burma beginnt das Druckereiwesen mit den Missionaren der amerikanischen Baptistenmission, die 1816 eine Druckerei begannen, welche allerdings 1824-1826 nach Calcutta verlegt wurde. Ein neues Druckereiunternehmen begann dann 1830.

Die Einführung des Druckereiwesens in Tbailand wird einem Missionar der Amerikanischen Missionsgesellschaft zugeschrieben, der 1835 in Bangkok anfing. Hier wurde auch 1844 die erste Zeitung der Stadt, der „Bangkok Recorder” gedruckt.

Für Indien begannen die Jesuiten 1556 in Goa mit ihrer ersten Druckerei, deren Maschinen eigentlich zuerst für Abessinien vorgesehen waren. 1573 wurde diese Druckerei geschlossen, und ihr folgte 1616 ein weiterer Versuch in Rachol bei Goa. Eine dritte Druckerei wurde $1642 \mathrm{im}$ neuen Kolleg von St. Paul in Goa begonnen. Ein spranischer Jesuitenbruder begann zwanzig Jahre nach der ersten Druckerei in Goa mit dem ersten Druckunternehmen in Malabar, wo er als erstes Werk in Malayalamübersetzung Franz Xavers „Doutrina Christâo” veröffentlichte. Weitere Druckereien folgten in anderen Teilen Indiens, so 1587 in Puniael bei Tinnevelly (für Tamil), 1602 in Vypicotta, 1679 in Ambalakad, 1674 in Bombay usw. Missionsdruckereien waren allerdings nicht immer willkommen oder geduldet von den Regierungsverantwortlichen. Die britische Kolonialmacht hatte z.B. in Indien Sorge, daß missionarische Aktivitäten die Stabilität der Regierung untergraben könnten. Deswegen waren Druckereien oft nur dort erlaubt, wo sie von den Autoritäten leicht kontrolliert werden konnten.

In Sri Lanka (Ceylon) begann der gleiche Generalgouverneur Baron Imhoff, der auch in Indonesien das Druckereiwesen förderte, mit der ersten Druckerei für holländische Missionare 1736. Als erstes wurde 1737 ein sinhalesisches Gebetbuch veröffentlicht. Nach der Übernahme der Insel durch Britannien 1796 begannen verschiedene andere Missionsgesellschaften mit Druckereien, und die Missionare selbst sind für die meisten periodischen Veröffentlichungen des Landes verantwortlich. So erschien z.B. 1833 das „Religious and Theological Magazine”.

Pakistan: Missionare verantworteten den ersten Druck in Panjab. Presbyterianische Missionare brachten eine Druckmaschine nach Ludhiana. Von 1836 bis 1841 erschien in der Ludhiana-Missionsdruckerei eine vierseitige Zeitung „Lodiana Akhbar” in persischer Sprache. 1873 wurde eine Wochenschrift „Noor Ufshan” in Persisch und Urdu gestartet. Trotz Rückschlägen war die Druckerei Hauptursprung christlichen Schrifttums für sämtliche Missionsgesellschaften im Nordwesten des Landes.

Aus dieser Übersicht der Geschichte der Missionsdruckereien und des Journalismus in Asien ergeben sich einige allgemeine Folgerungen:

1. Sowohl die Kolonialverwaltung als auch die Kirchenverantwortlichen haben die Bedeutung der Presse für ihre Aufgaben erkannt. 
2. Zwar wurden die Druckereien hauptsächlich für das Bekehrungswerk eingesetzt, aber die neue Technik half auch u.a. durch die Veröffentlichung von Grammatiken und Wörterbüchern die asiatischen Sprachen als Schriftsprachen zu entwickeln und etwa Drucktypen für die verschiedenen Sprachen des Kontinents zu schaffen. Allerdings wurde dadurch auch westliche Überlegenheit demonstriert.

3. Die von Missionaren geschaffenen Zeitschriften waren die Vorboten des modernen Journalismus in Asien.

4. Einige Einzelpersörtlichkeiten der Missionapresse waren dem Druckwesen besonders verpflichtet und wanderten zum Teil durch verschiedene Länder und Teile des Kontinents zur Verbreitung der Presse.

5. Durch die missionarischen Aktivitäten entstanden Druckereizentren, wie z.B. in Macao und Goa, die der Aus- und Weiterbildung von Fachleuten und auch der Nutzung maschineller Möglichkeiten (z.B. Drucktypen) dienten.

\section{RÉSUMÉ}

Dans l'histoire de l'imprimerie, il existe des liens étroits entre le christianisme et les imprimeries d'autrefois, pas seulement en Europe, mais également dans beaucoup de pays non chrétiens d'autres continents. En ce qui concerne l'exemple de l'Asie, l'auteur en fournit la preuve avec documents à l'appui. Les missionnaires, catholiques comme protestants, construisirent dans les pays, l'un après l'autre, en tout premier lieu des imprimeries et fondèrent des journaux. Dès le $17 \mathrm{e}$ siècle, les missionnaires catholiques imprimèrent et publièrent du moins à Macao, au Japon aux Philippines et en Inde. Plus tard suivirent des missionnaires protestants originaires des EtatsUnis et d'Europe, et ils commencèrent les premières imprimeries et journaux, ainsi en Birmanie, en Thailande, en Malaisie, à Singapour, en Indonésie, et en quelques parties de Chine. Des noms de missionnaires sont connus depuis longtemps pour le journalisme en Asie, même au $19 \mathrm{e}$ siècle. Le reportage de l'auteur au sujet de la presse missionnaire en Asie Orientale et en Asie du Sud-est, de même qu'en Asie méridionale entre 1550 et 1860 donne une image variée des précurseurs en matière de presse de là-bas, vis-à-vis de ceux d'aujourd'hui.

\section{RESUMEN}

En la Historia de las Artes Gráficas existen estrechas vinculaciones entre el Cristianismo y las primeras imprentas, no sólo en Europa, sino también en muchos países no cristianos de otros continentes. A modo de ejemplo, el autor aporta pruebas relativas a Asia. Misioneros católicos y protestantes crearon las primeras imprentas en un país tras otro y fundaron revistas. Ya en el siglo XVII los misioneros católicos eran impresores y editores al menos en Macao, Japón, Filipinas e India. Les siguieron misioneros protestantes de Estados Unidos y Europa, que crearon las primeras imprentas y revistas por ejemplo en Birmania, Thailandia, Malasia, Singapur, Indonesia y puntos diversos de China. También en el siglo XIX aparecen nombres de misioneros vinculados al periodismo en Asia. El estudio del autor sobre la prensa misionera en el este, sudeste y sur de Asia, de 1550 a 1860, ofrece una panorámica múltiple de los precursores de la prensa local actual. 